\title{
The Distribution and Abundance of Mussels (Bivalvia: Unionidae) in Lower Big Walnut Creek from Hoover Dam to its Mouth, in Franklin and Pickaway Counties, Ohio
}

MICHAEL A. HOGGARTH, 'Department of Biology and Earth Science, Otterbein University, and Stone Environmental Engineering and Science, Inc., Westerville, OH, USA, and MICHAEL GRUMNEY, Columbus Zoo and Aquarium, Powell, OH, USA.

ABSTRACT. Big Walnut Creek in central Ohio once supported a mussel fauna of 40 species, but no systematic study of the mussels of the creek has been done. The objective of the current study was to determine the distribution and abundance of mussels in Big Walnut Creek downstream of Hoover Dam (RM 36.7) to its mouth with the Scioto River. The extant (living and freshly dead shells) and total (extant plus weathered and subfossil shells) mussel communities were determined at 21 sites. Two techniques were used to determine the mussel community at each site: timed searches and transect/quadrat sampling. Shannon-Weiner $\left(\mathrm{H}^{\prime}\right)$ values, Jaccard Coefficient of similarity values, and percent extant species were calculated for the mussel communities at each location. Student T-tests were used to determine where a significant change in community structure occurred based on the metrics listed above. The mussel communities from Hoover Dam to Whitehall (RM 22.0) had maintained their diversity. The historic and extant communities in this reach were essentially the same (Jaccard Coefficient $=83$ percent and percent extant species $=78$ percent) with $\mathrm{H}^{\prime}$ values for this reach not significantly different when comparing the total and extant communities $(t=1.08, p>0.05)$. The communities from RM 22.0 to RM 15.0 (just downstream of Three Rivers MetroPark) had fewer extant species (Jaccard Coefficient and percent extant values of 62 percent and 36 percent, respectively), and significantly diminished species diversity $(t=2.35, p<0.05)$. Diminished species diversity continued to be expressed downstream $(t=2.48, p<0.05)$, with some recovery (Jaccard Coefficient $=67$ percent and percent extant $=42$ percent) as we approached the mouth of the creek. This improvement may be a result of movement of mussels (as larvae attached to fish hosts) from the Scioto River.

\section{INTRODUCTION}

The distribution of the mussels of Big Walnut Creek is not well known. This is a bit surprising given the location of the stream in central Ohio and its proximity to other known mussel rich streams, such as Big Darby Creek, the Scioto River and the Olentangy River (Watters 1998; Hoggarth 1990; Watters et al. 2009). Nonetheless, Hoggarth (1997) found a good diversity of overall species and rare species of mussels in the Lockbourne Road area. He documented the occurrence of 28 species of mussels in this reach including specimens of one federally listed endangered species, Epioblasma triquetra (snuffbox), one federally listed threatened species, Quadrula cylindrica (rabbitsfoot), one Ohio endangered species, Megalonaias nervosa (washboard), one Ohio threatened species, Truncilla donaciformis (fawn foot), and seven species currently listed as species of concern in the state, Anodonta suborbiculata (round floater),

${ }^{1}$ Address correspondence to Michael A. Hoggarth, Department of Biology and Earth Science, Otterbein University, Westerville, OH 43081. E-mail: mhoggarth@otterbein.edu
Alasmidonta marginata (elktoe), Lasmigona compressa (creek heelsplitter), Pleurobema sintoxia (round pigtoe), Ptychobranchus fasciolaris (kidneyshell), Truncilla truncata (deertoe), and Lampsilis fasciola (wavyrayed pocketbook). Historic data reveal that the creek once supported 40 species of mussels (Watters et al. 2009), and 44 species of fish (OEPA 2003). Furthermore, using the Index of Biological Integrity (IBI), OEPA (2003) recorded fish IBI scores from 34 immediately downstream of Hoover Dam to 48 near its mouth. An IBI of 60 is the highest score attainable based on the indicators in the index. The Qualitative Habitat Evaluation Index (QHEI) scores from 82.0-84.5 out of 100 throughout the lower portion of the creek also suggest high water quality which would support species diversity. These data suggest the stream's mussel fauna should be examined.

The objective of the current survey, therefore, was to determine the distribution and abundance of the mussels of the lower Big Walnut Creek from Hoover Dam to the mouth of the creek with the Scioto River (Fig. 1). No systematic survey of the mussels of 


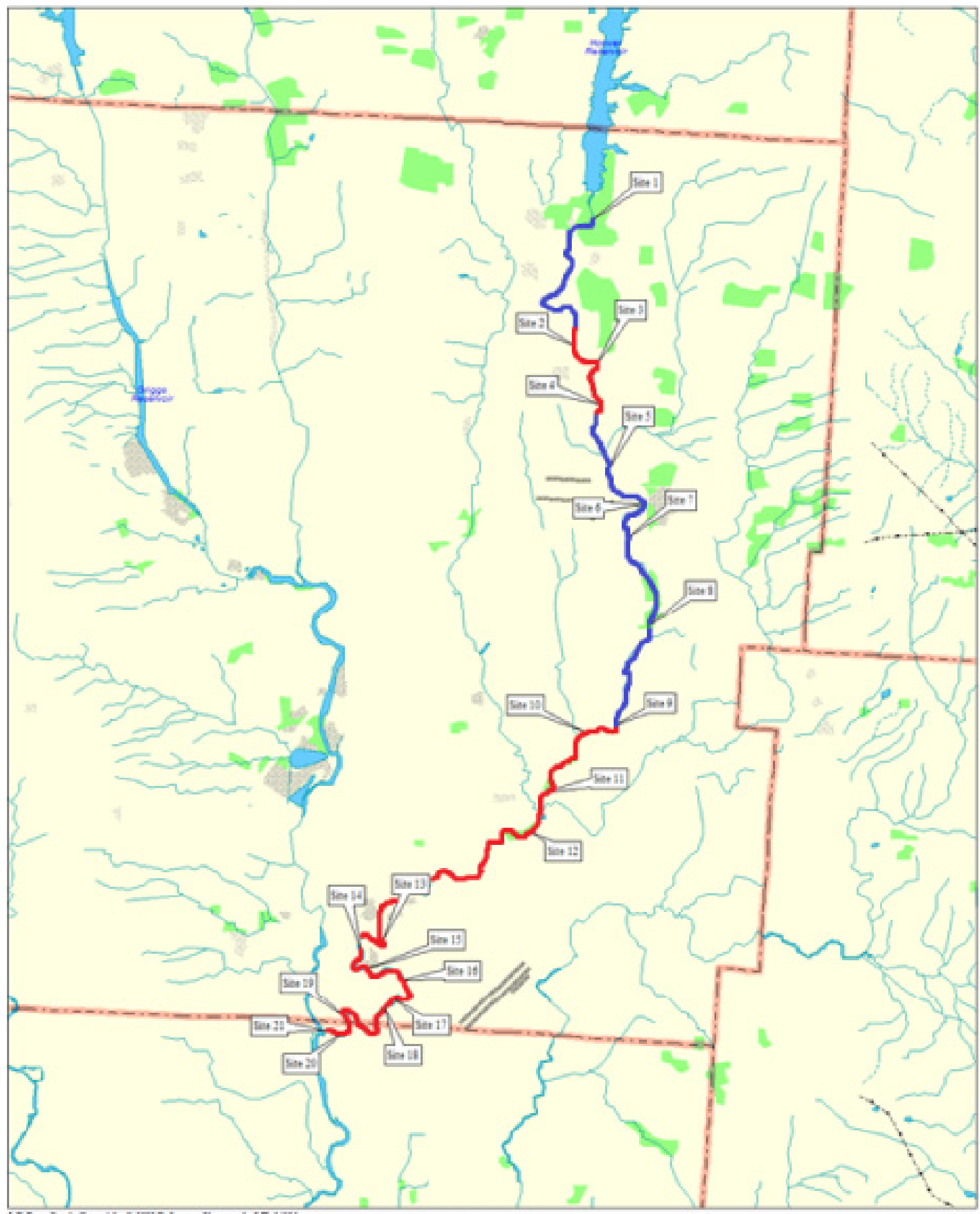

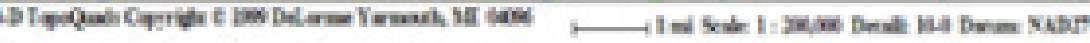

FIGURE 1. Map of the Big Walnut Creek watershed from Hoover Dam to its mouth showing the 21 sample locations, the canoed reaches (red) and where access was from the bridges (blue.) 
the watershed has ever been done even though the creek has the potential to support at least 40 species (Watters et al. 2009), including rare species (Hoggarth 1997). All of these are enhanced by the improved quality of the Scioto River (OEPA 2012) and the proximity the mouth of Big Walnut Creek has with Big Darby Creek, one of the most ecologicallydiverse watersheds in the country with exceptional water quality (OEPA 2015). It is possible that the two smaller streams are now effectively connected through the Scioto River so that species might be exchanged.

\section{Site Description}

MATERIALS AND METHODS

Big Walnut Creek has its beginning approximately one mile southwest of Mount Gilead, Ohio in Morrow County and flows south, running parallel to Alum Creek. As Big Walnut Creek flows east of Sunbury, it crosses into Delaware County and flows into Hoover Reservoir. From Hoover Reservoir, the creek continues south through Gahanna and Whitehall, and enters Three Rivers MetroPark, where it is met by its two major tributaries: Alum Creek and Blacklick Creek. Big Walnut Creek continues southward through Franklin County and enters Pickaway County before emptying into the Scioto River (Fig. 1).

The study area included Big Walnut Creek from the outflow of Hoover Reservoir to the mouth of the creek at the Scioto River (Fig. 1). The entire length of Big Walnut Creek below Hoover Reservoir was surveyed, but specific sample sites were determined by identifying optimal habitat for mussels. These optimal areas included shallow riffles along the outer edges of the creek away from deep, slow moving pools. We sampled 21 sites either by gaining access from bridges or by canoeing during the time period of 1 September 2012 and 13 October 2012. One additional site (Site 5) was sampled on 16 May 2012. Table 1 gives the location and date of sampling of each of the 21 sites.

\section{Methods}

Mussels were collected during timed searches and quadrat sampling. Time searches involved a $45 \mathrm{~min}$ ute visual search of a 200 meter reach of stream by two collectors for a total of 90 minutes per site. All whole mussels found (alive or dead) were collected, identified, counted and then returned to the stream.
In quadrat sampling, two transects (one per surveyor), each 10 meters long, were sampled. A total of 20, $1 / 4$ meter $^{2}$ quadrats per transect was sampled by each surveyor. Each surveyor first used a viewer to scan the substrate for obvious live mussels or mussel shells, followed by using tools to excavate each quadrat to a depth of $15 \mathrm{~cm}$. All mussels collected were identified and counted as either living, freshly dead (soft tissue present, nacre lustrous, and no erosion of the shell), weathered (dead and noticeable internal/ external erosion of shell with possible staining), or subfossil (little to no periostracum remaining with the internal/external shell often faded to white). The living and freshly dead component of the collection was determined to represent the extant population at the site regardless of finding weathered and subfossil specimens. If only weathered and subfossil specimens were found, then this component of the collected mussels was determined to represent an extirpated species for the site.

\section{Analysis}

The numeric data on live and dead mussels were collected to determine mussel diversity, abundance, and overall community structure throughout the study area. The Shannon-Wiener Diversity Index (H') was used to measure diversity throughout the stream. Two indices of diversity were calculated for each sample: 1) the diversity of extant individuals and 2) the total diversity at the site represented by extant and extirpated individuals. This was done to identify if the extant diversity was similar to the total diversity of mussels at each site. The Jaccard Coefficient of Similarity and percent extant species also were calculated to assess if the two communities (extant and total) were similar or not. Jaccard Coefficient of Similarity examines the degree to which two groups of species are similar and percent extant species examines how many of the historic taxa at a site are still present at that site. A Student T-test was used to measure significant differences in mussel community from site to site.

\section{Mussel Diversity}

\section{RESULTS}

During the current study, 31 species of mussels were found alive or as dead shells (freshly dead, weathered dead and subfossil shells). Of this number, 24 species were found to be extant (either collected alive or as freshly dead shells) and seven were only 
TABLE 1

Sample locations for a mussel study of lower Big Walnut Creek

Site 1: Big Walnut Creek downstream of Central College Road, at $40.097607^{\circ} \mathrm{N}-82.880414^{\circ} \mathrm{W}$, Franklin Co., Ohio, on 1 September 2012 and 2 September 2012.

Site 2: Big Walnut Creek downstream of Morse Road, at $40.051029^{\circ} \mathrm{N}-82.890739^{\circ} \mathrm{W}$, Franklin Co., Ohio, on 9 September 2012.

Site 3: Big Walnut Creek at Woodside Green Park, at $40.044091^{\circ} \mathrm{N}-82.879978^{\circ} \mathrm{W}$, Franklin Co., Ohio, on 22 September 2012.

Site 4: Big Walnut Creek adjacent to Gahanna Municipal GolfCourse, at $40.029562^{\circ} \mathrm{N}-82.877703^{\circ} \mathrm{W}$, Franklin Co., Ohio, on 29 September 2012.

Site 5: Big Walnut Creek at the IR 270 Bridge, at $40.006664^{\circ} \mathrm{N}-82.874567^{\circ} \mathrm{W}$, Franklin Co., Ohio, on 29 September 2012.

Site 6: Big Walnut Creek at Airport Golf Course downstream of Pizzuro Park, at $39.993509^{\circ} \mathrm{N}-82.857756^{\circ} \mathrm{W}$, Franklin Co., Ohio, on 29 September 2012.

Site 7: Big Walnut Creek at Whitehall Community Center, at $39.981531^{\circ} \mathrm{N}-82.863957^{\circ} \mathrm{W}$, Franklin Co., Ohio, on 30 September 2012.

Site 8: Big Walnut Creek at Big Walnut Park, at $39.949177^{\circ} \mathrm{N}-82.854546^{\circ} \mathrm{W}$, Franklin Co., Ohio, on 30 September 2012.

Site 9: Big Walnut Creek at Nerfzgel Park, at 39.912873N $-82.870410^{\circ} \mathrm{W}$, Franklin Co., Ohio, on 4 October 2012.

Site 10: Big Walnut Creek downstream of Hamilton Road (SR 317), at 39.910023N -82.883249W, Franklin Co., Ohio, on 4 October 2012.

Site 11: Big Walnut Creek at East Williams Road, at $39.887874^{\circ} \mathrm{N}-82.905006^{\circ} \mathrm{W}$, Franklin Co., Ohio, on 11 October 2012.

Site 12: Big Walnut Creek downstream of Three Rivers MetroPark, at $39.873349^{\circ} \mathrm{N}-82.912382^{\circ} \mathrm{W}$, Franklin Co., Ohio, on 11 October 2012.

Site 13: Big Walnut Creek upstream of London-Groveport Bridge (SR 17), at $39.833993^{\circ} \mathrm{N}-82.980494^{\circ} \mathrm{W}$, Franklin Co., Ohio, on 13 September 2012.

Site 14: Big Walnut Creek downstream of London-Groveport Bridge (SR 317), at 39.831382 $\mathrm{N}-82.992654^{\circ} \mathrm{W}$, Franklin Co., Ohio, 13 September 2012.

Site 15: Big Walnut Creek adjacent to gravel quarry, at $39.823557^{\circ} \mathrm{N}-82.990004^{\circ} \mathrm{W}$, Franklin Co., Ohio, on 15 September 2012.

Site 16: Big Walnut Creek off of Lockbourne Road, at $39.819118^{\circ} \mathrm{N}-82.970161^{\circ} \mathrm{W}$, Franklin Co., Ohio, on 16 September 2012. 
TABLE 1 (cont.)

Sample locations for a mussel study of lower Big Walnut Creek

Site 17: Big Walnut Creek upstream of Rowe Road Bridge (CR 133), at 39.812071 ${ }^{\circ} \mathrm{N}-82.969446^{\circ} \mathrm{W}$, Franklin Co., Ohio, on 16 September 2012.

Site 18: Big Walnut Creek downstream of Rowe Road Bridge (CR 133), at 39.809502 $\mathrm{N}-82.977974^{\circ} \mathrm{W}$, Franklin Co., Ohio, on 13 October 2012.

Site 19: Big Walnut Creek downstream of US Rt. 23 Bridge, at $39.8806785^{\circ} \mathrm{N}-82.996485^{\circ} \mathrm{W}$, Franklin Co., Ohio, on 20 September 2012.

Site 20: Big Walnut Creek further downstream of US Rt. 23 Bridge, at $39.80012^{\circ} \mathrm{N}-83.004117^{\circ} \mathrm{W}$, Pickaway Co., Ohio, on 20 September 2012.

Site 21: Big Walnut Creek just upstream of its mouth, at $39.799587^{\circ} \mathrm{N}-83.007799^{\circ} \mathrm{W}$, Pickaway Co., Ohio, on 20 September 2012.

found as weathered or subfossil shells (Table 2). Of the 24 species found to be extant, one (M. nervosa, washboard) is an Ohio endangered species and another (L. recta, black sandshell) is listed as threatened in the state. Other state significant species found alive during this study (all Ohio species of concern) were A. marginata (elktoe), P. fasciolaris (kidneyshell), $T$. truncata (deertoe), and $L$. fasciola (wavy-rayed pocketbook). In addition to the six species listed above, four federally listed and Ohio endangered species $(Q$. cylindrica, rabbitsfoot; $P$ clava, clubshell; E. triquetra, snuffbox; and E. t. rangiana, northern riffleshell), one additional Ohio threatened species ( $T$. donacifor$m i$, fawn foot), and one Ohio species of concern $(P$. sintoxia, round pigtoe) were found only as extirpated specimens.

Four species comprised more than 10 percent each of the entire fauna (extant and extirpated) and were widely distributed throughout the study area (Table 2 ). The most abundant extant species by percent of total were Elliptio dilatata (spike) (16.7 percent), Potamilus alatus (pink heelsplitter) (15.9 percent), Leptodea fragilis (fragile papershell) (14.8 percent) and Lampsilis radiata luteola (fatmucket) (10.9 percent). Elliptio dilatata (spike) was most commonly found in the upper reaches of the survey area whereas P. alatus (pink heelsplitter) and L. fragilis (fragile papershell) were more commonly found in the middle to lower reaches. Elliptio dilatata (spike), Amblema plicata (threeridge), and Fusconaia flava (Wabash pigtoe) were the most likely species to be found as weathered or subfossil shells with $E$. dilatata (spike) being found predominantly in the upper to middle reaches, $A$. plicata (threeridge) in the middle to lower reaches, and $F$. flava (Wabash pigtoe) in the upper reaches.

The number of extant individuals outnumbered the extirpated individuals at sites 1-8, 12-17, and 1920 (Figure 2). The number of extirpated individuals was only greatest at sites 9-11, 18, and 21 . In the upper reaches (sites 1-7), more extant species were found than extirpated species except at site 2 (Fig. 3 ). In the middle reaches (sites 8-14), extant species outnumbered the extirpated species found except at sites 10 and 11 . In the lower reaches (sites 15-21), the number of extirpated species was greater than the number of extant species at every site except site 15 .

The mussel communities from Hoover Dam to Whitehall (RM 22.0) changed very little (Jaccard Coefficient $=83$ percent and percent extant $=78$ percent) when comparing the historic (all mussels collected) and extant (only the freshly dead and live mussels) communities (Table 3). In this section of the creek, total and extant diversity ( $\mathrm{H}^{\prime}$ values) were not significantly different $(\mathrm{t}=1.08, \mathrm{p}>0.05)$ (Fig. 4). However, the communities from RM 22.0 to RM 15.0 (just downstream of Three Rivers MetroPark) had fewer extant species (Jaccard Coefficient and percent extant values of 62 percent and 36 percent) and significantly diminished species diversity $(\mathrm{t}=$ 2.35, $\mathrm{p}<0.05)$. Diminished species diversity continued to be expressed downstream $(t=2.48, \mathrm{p}<0.05)$, with some recovery (Jaccard Coefficient $=67$ percent and percent extant $=42$ percent ) found in the lower 
Table 2

Extant (live and freshly dead collected) and extirpated (weathered and subfossil collected) mussels collected from Big Walnut Creek in Franklin and Pickaway counties, Ohio, in 2012.

Species

Common Name

\section{Extant}

\# $\%$

1. Pyganodon grandis

2. Strophitus undulatus

3. Alasmidonta marginata ${ }^{\mathrm{d}}$

4. Lasmigona costata

5. Lasmigona complanata

6. Tritogonia verrucosa

7. Quadrula cylindrica ${ }^{a}$

8. Quadrula quadrula

9. Quadrula pustulosa

10. Amblema plicata

11. Cyclonaias tuberculata

12. Fusconaia flava

13. Pleurobema sintoxia ${ }^{\mathrm{d}}$

14. Pleurobema clava ${ }^{\mathrm{a}}$

15. Elliptio dilatata

16. Megalonaias nervosa ${ }^{\mathrm{b}}$

17. Ptychobranchus fasciolaris ${ }^{\mathrm{d}}$

18. Leptodea fragilis

19. Potamilus alatus

20. Potamilus ohiensis

21. Truncilla donaciformis ${ }^{c}$

22. Truncilla truncata ${ }^{\mathrm{d}}$ giant floater

creeper

elktoe

fluted shell

white heelsplitter

pistolgrip

rabbitsfoot

mapleleaf

pimpleback

threeridge

purple pimpleback

Wabash pigtoe

51

round pigtoe

clubshell

spike

$115 \quad 16.7$

0.3

kidneyshel

fragile papershell

$102 \quad 14.8$

pink heelsplitter

$110 \quad 15.9$

pink papershell

2

fawnsfoot

deertoe
10

11

Extirpated

2

2

1

14

9

1

11

8

28

4

24

5

1

39

18

0

2

6 
Table 2 (cont.)

Extant (live and freshly dead collected) and extirpated (weathered and subfossil collected) mussels collected from Big Walnut Creek in Franklin and Pickaway counties, Ohio, in 2012.

\section{Species}

Common Name
Extirpated
23. Obovaria subrotunda

24. Toxolasma parvum

25. Ligumia recta ${ }^{\mathrm{c}}$

26. Villosa iris

27. Lampsilis radiata luteola

28. Lampsilis cardium

29. Lampsilis fasciola ${ }^{\mathrm{d}}$

30. Epioblasma triquetra ${ }^{\text {a }}$

\section{Epioblasma torulosa rangiana ${ }^{a}$}

Total number of species

Total number of individuals hickorynut

lilliput

black sandshell

rainbow

fatmucket

plain pocketbook

wavy-rayed pocketbook

snuffbox

northern riffleshell
6

$1 \quad 0.1$

$\begin{array}{ll}5 & 0.7\end{array}$

1

$13 \quad 1.9$

$\begin{array}{ll}75 & 10.9\end{array}$

16

$49 \quad 7.1$

7

2

5

1

28

690

${ }^{a}=$ Federally listed and Ohio endangered species; ${ }^{b}=$ Ohio endangered species; ${ }^{c}=$ Ohio threatened species; ${ }^{d}$ $=$ Ohio species of concern.

reaches of the creek. We believe some of this recovery in the extreme lower reaches of Big Walnut Creek may be the result of movement of mussels from the Scioto River, which has diverse fish and macroinvertebrate communities (OEPA 2012). In addition, although the relationship between H'-Extant and H'Total was not significant (Fig. 5) $\left(\mathrm{r}^{2}=0.3343\right.$, $\mathrm{p}>$ 0.05 ), it does demonstrate that where the number of extant species were highest (as in the most species rich sites, including some in the lower reaches of the creek), the two values follow the regression line almost exactly. This finding suggests a great deal of potential recovery for the mid-section of the creek.

\section{DISCUSSION}

Lower Big Walnut Creek has suffered mussel species loss. Of the 40 species historically found in the Big Walnut Creek (Watters et al. 2009), only 31 were found during this survey (some of the 40 species are headwaters species that would not be expected in the section examined during this study), and of these 31 species, only 24 were found to have extant populations. We found that the mussels in

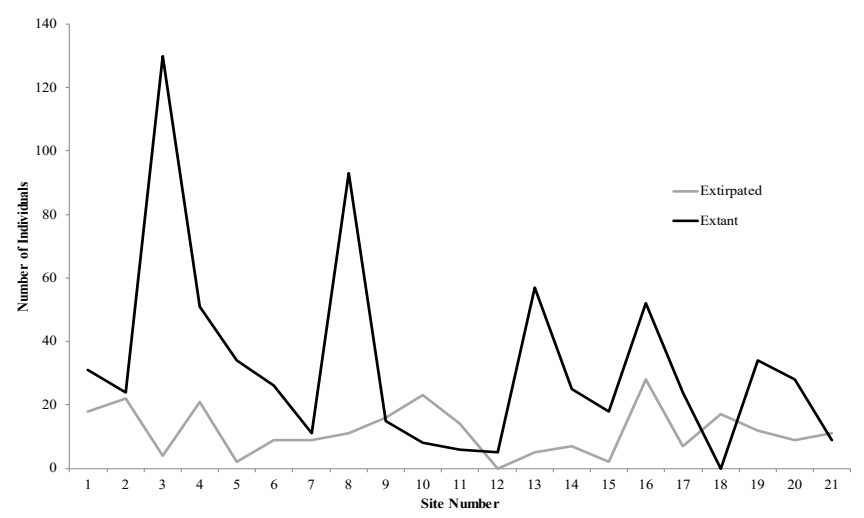

FIGURE 2. Line graph showing the relationshop between the number of extant and extrirpated individuals collected from each collection site from below Hoover Reservoir (Site 1) to immediately above its mouth (Site 21). 
Table 3

Shannon-Weiner Diversity Index, Jaccard Coefficient of Similarity values, and percent extant species values for the mussels collected from

Big Walnut Creek in Franklin and Pickaway counties, Ohio in 2012.

\begin{tabular}{|c|c|c|c|c|}
\hline Site \# & $\mathrm{H}^{\prime}$ Extant & H'Total & $\begin{array}{c}\text { Jaccard } \\
\% \text { Similarity }\end{array}$ & $\%$ Extant \\
\hline 1 & 0.6642 & 0.6761 & 89 & 88 \\
\hline 2 & 0.5353 & 0.7495 & 69 & 55 \\
\hline 3 & 0.7310 & 0.7593 & 86 & 83 \\
\hline 4 & 0.8975 & 0.9849 & 79 & 73 \\
\hline 5 & 0.9089 & 0.9608 & 87 & 85 \\
\hline 6 & 0.7068 & 0.8694 & 77 & 70 \\
\hline 7 & 0.5936 & 0.7088 & 78 & 63 \\
\hline 8 & 1.0369 & 1.0428 & 100 & 100 \\
\hline 9 & 0.7782 & 0.9666 & 67 & 50 \\
\hline 10 & 0.6021 & 1.0066 & 61 & 36 \\
\hline 11 & 0.3768 & 1.0488 & 57 & 23 \\
\hline 12 & 0.4582 & 0.4582 & $--^{b}$ & 100 \\
\hline 13 & 0.5448 & 0.6282 & 82 & 78 \\
\hline 14 & 0.5579 & 0.7549 & 75 & 67 \\
\hline 15 & 0.4403 & 0.5676 & $--b$ & 67 \\
\hline 16 & 0.4326 & 1.1468 & 68 & 52 \\
\hline 17 & 0.8537 & 1.0487 & 70 & 57 \\
\hline 18 & 0.0000 & 0.3510 & $--b$ & 0 \\
\hline 19 & 0.5951 & 0.9071 & 62 & 39 \\
\hline 20 & 0.7362 & 0.9554 & 74 & 64 \\
\hline 21 & 0.4990 & 0.9125 & 63 & 40 \\
\hline \multicolumn{5}{|c|}{$\mathrm{a}=\mathrm{a}$ comparison of extant and total community similarity } \\
\hline
\end{tabular}


the upper portion of the study area (from Hoover Dam to Whitehall) suffered the least decline in species, while the mid-section (from Whitehall to Three

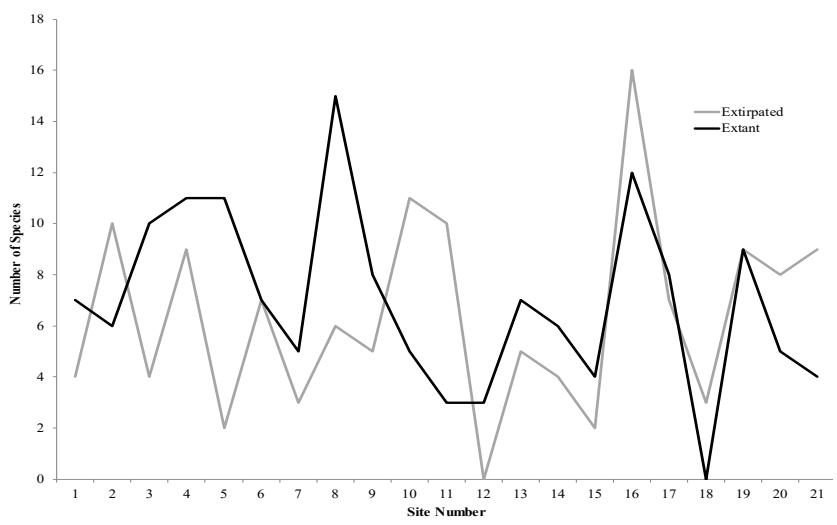

FIGURE 3. Line graph showing the relationship between the number of extant and extirpated individuals collected from each collection site from Big Walnut Creek from below Hoover Reservoir (Site 1) to immediately above its mouth (Site 21).

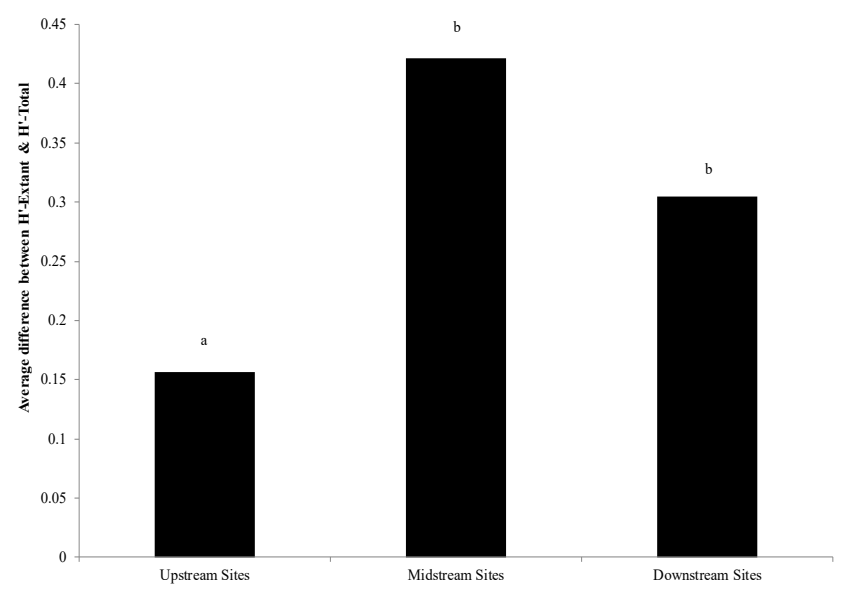

FIGURE 4. Line graph showing the relationship between the number of extant and extirpated species collected from each collection site from Big Walnut Creek from below Hoover Reservoir (Site 1) to immediately above its mouth (Site 21).

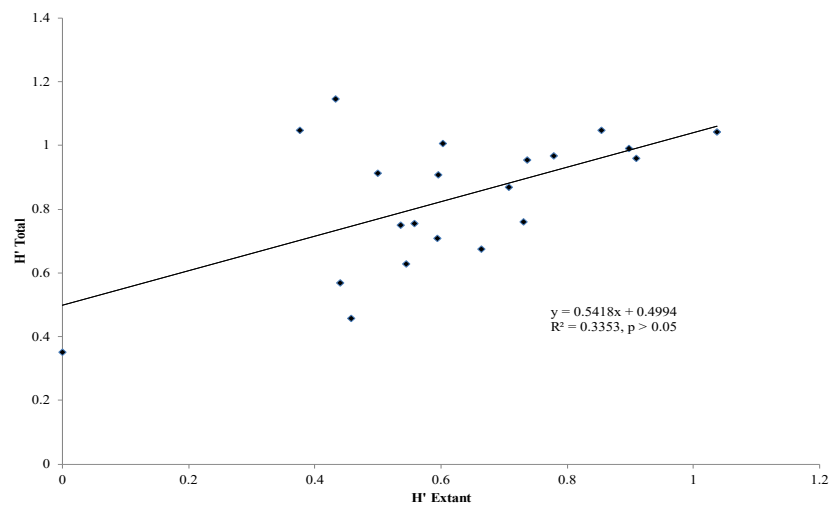

FIGURE 5. Average difference between the total community ( $\mathrm{H}^{\prime}$-Total) and the extant community ( $\mathrm{H}^{\prime}$-Extant) for the mussel communities of Big Walnut Creek. The upstream sites are sites $1-7$, the midstream sites are $8-14$, and the downstream sites are sites 15-21. $\mathrm{a}=$ no significant difference between the $\mathrm{H}^{\prime}$-Total and $H^{\prime}$ Extant and $b$ shows a significant difference between the two measures of community diversity $(p<0.05)$
Rivers MetroPark) and the lower section (from Three Rivers MetroPark to the mouth) suffered the most species loss and currently supports the least diversity of mussels. These data are in sharp contrast to what Ohio EPA found for the fish (IBI) and invertebrate communities (OEPA 2003). Reasons for this may be the 13 years which have elapsed since Ohio EPA performed their study and that the water quality of the upper section has improved while that in the lower sections has declined. A more probable reason is that mussels tell a different story about water resource integrity than fish and other invertebrates. Mussels are long-lived species that cannot move away from an area when it is degraded. They show a graded response at the species level to degradation, and they depend on other species (generally fish) to complete their life cycle. Given these facts, they are excellent indicators of long-term water resource integrity both in regard to the maintenance of stream health (like the upper reaches of the current study) and the degradation of the health of a reach (the mid and lower sections of Big Walnut Creek).

The fact that mussels tell us more about the longterm quality of the aquatic resources rather than the more immediate integrity of the resource can lead to difficulty interpreting sampling data. For example, we noticed many very old (perhaps 20-35 years old) mussels dead in situ in the lower portion of the creek (especially at sites 16 and 17: off of Lockbourne Road and upstream of the Rowe Road Bridge). The substrate around these shells had been mostly washed away. These observations suggest these mussels were killed almost immediately (they did not try to move from the reach) and that they had been dead for a very long time. It suggests an unknown water quality issue killed these mussels (old age is not suspected since there were so many shells in exactly the same position in the stream), but it is difficult to say when this occurred other than to say it was some years ago. The fact that these same two sites produced relatively large numbers of living mussels, including rare species, suggests the same water quality issues are not being experienced today. However, it is interesting that many of the species that were eliminated (mostly species that completely bury in the substrate) are still gone. This could be due to some latent problem associated with the substrate or it could be access, as many of these species (such as Lasmigona costata, fluted-shell) are fairly rare to absent in much of the lower portion of the creek. Still, some analysis and 
interpretation of the mussel data we collected is in order.

\section{The Upper Section (from Hoover Dam to Whitehall; Sites 1-7)}

As noted previously, this section of the creek suffered the least species loss and had the highest diversity. Sites 1-4 are located upstream of the lowhead dam in Gahanna, while the remaining four sites are located from Gahanna to Whitehall. Site 3 (at Woodside Green Park) and Site 4 (adjacent to the Gahanna Municipal Golf Course) produced numerous live and freshly dead mussels. Only two other sites, Site 8 (at Big Walnut Park) and Site 16 (off of Lockbourne Road) produced similar numbers of live mussels.

The highest diversity sites in this section (Sites 3 and 4) had significant riparian corridors and were more or less protected from further development by being adjacent to a park and a golf course. The creek in these two areas had a natural channel without evidence of excessive nutrient and/or other pollutants entering the stream. Most of the live mussels found in these two reaches were completely buried in the substrate and fairly densely packed (Site 3 had an average density of 10 mussels $/ \mathrm{m}^{2}$ and Site 4 had an average density of four mussels $/ \mathrm{m}^{2}$ ). For comparison, Site 8 had an average density of six mussels $/ \mathrm{m}^{2}$ and Site 16 had an average density of zero mussels/ $\mathrm{m}^{2}$ from the quadrat sampling, but produced many more live mussels during the timed searches.

The recovery potential for the mussel community in this reach varies depending on where the mussels are currently found.

The recovery potential of Sites $1-4$ are reduced by their location between Hoover Dam and the lowhead dam in Gahanna. It seems unlikely that fish with glochidia (the parasitic larvae of mussels) will be able to move upstream of the lowhead dam (Watters 1996), and so recruitment of new species from downstream will be limited, or that fish with glochidia will emerge from outflow of water from Hoover Reservoir, since the reservoir does not support a riverine fauna of mussels. The section of the creek upstream of Site 3 could benefit from immigration; however, this too is limited by the presence of the lowhead dam at the Hap Cremean Water Plant. The recovery potential of Sites 5-7, however is enhanced by the presence of Site 8 (Big Walnut Park), which produced a large number of live mussels.

\section{The Mid-Section (from Whitehall to State Route 317; sites 8-14)}

Other than Site 8 (Big Walnut Park), this reach of stream suffered the highest degree of mussel loss examined during this study. This was surprising as this reach had the highest Fish-IBI scores and Invertebrate Community Index (ICI) scores of any of the stations examined by OEPA in 2000 (OEPA 2003). As noted above, Site 8 is a diverse mussel community (an average density of six mussels $/ \mathrm{m}^{2}$ ) with many species, such as $E$. dilatata that completely bury in the substrate (generally an indication of overall good, long-term habitat and water quality). As at Sites 3 and 4 , the creek at this site was fairly protected with a good riparian corridor and the substrate in the creek was stable and composed of sediments ideal for mussels (sand and gravel). There was no indication of excessive nutrients and/or other pollutants in the water (no excessive algae growth, for example).

These same conditions were found just upstream and downstream of Three Rivers MetroPark (as well as within the park itself), but very few mussels were found at the two sites on either side of the metropark (Sites 11 and 12) or within the metropark (no station was established in the metropark as no area of mussel concentration was found). Otherwise, this reach was dominated by narrow riparian corridors and some stretches indicating excessive nutrient loading (excessive algae covering the substrate) was apparent. Ohio EPA (OEPA 2003) identified some wastewater treatment issues associated with Alum and Blacklick creeks, which may have influenced water quality below Three Rivers MetroPark historically, but these problems have mostly been solved. Still, the mussels are reacting negatively to these disturbances, but have the potential to improve by immigrating from Site 8 and from the lower section of the river since there are no dams in this portion of the creek to impair movement of mussels.

\section{The Lower Section (from State Route 317 to the mouth; sites 15-21)}

Whatever has affected the mid-section of Big Walnut Creek may also have affected the lower section of the creek. In addition, there are potentially other developments in the lower sections, such as sand and gravel operations (Hoggarth 1997; OEPA 2003) that would add to the problems for mussels in this reach. Still, this reach appears to have experienced limited recovery. For example, even though $L$. recta 
Table 4

Mussels recently collected from the Scioto River near the mouth of Big Walnut Creek by Hoggarth

\begin{tabular}{|c|c|c|c|c|c|c|c|c|}
\hline \multirow[t]{2}{*}{ Species } & \multicolumn{2}{|c|}{1} & \multicolumn{2}{|c|}{2} & \multicolumn{2}{|c|}{3} & \multicolumn{2}{|c|}{4} \\
\hline & \# & $\%$ & $\#$ & $\%$ & $\#$ & $\%$ & $\#$ & $\%$ \\
\hline 1. Utterbackia imbecillis & 1 & 0.6 & 0 & 0.0 & 1 & 0.2 & 0 & 0.0 \\
\hline 2. Anodonta subrotunda & 1 & 0.6 & 0 & 0.0 & 1 & 0.2 & 0 & 0.0 \\
\hline 3. Pyganodon grandis & 0 & 0.0 & 0 & 0.0 & 4 & 0.6 & 1 & 0.1 \\
\hline 4. Alasmidonta marginata & 0 & 0.0 & 0 & 0.0 & 0 & 0.0 & 2 & 0.3 \\
\hline 5. Lasmigona costata & 1 & 0.6 & 0 & 0.0 & 0 & 0.0 & 0 & 0.0 \\
\hline 6. Lasmigona complanata & 12 & 6.9 & 10 & 6.27 & 5 & 11.8 & 45 & 6.2 \\
\hline 7. Amblema plicata & 4 & 2.3 & 0 & 0.0 & 7 & 1.1 & 4 & 0.6 \\
\hline 8. Tritogonia verrucosa & 22 & 12.6 & 1 & 0.6 & 1 & 0.2 & 2 & 0.3 \\
\hline 9. Quadrula quadrula & 27 & 15.5 & 63 & 39.1 & 178 & 28.1 & 242 & 33.3 \\
\hline 10. Quadrula pustulosa & 1 & 0.6 & 4 & 2.5 & 1 & 0.2 & 4 & 0.6 \\
\hline 11. Fusconaia flava & 1 & 0.6 & 0 & 0.0 & 0 & 0.0 & 0 & 0.0 \\
\hline 12. Leptodea fragilis & 52 & 29.9 & 0 & 0.0 & 152 & 24.0 & 135 & 18.6 \\
\hline 13. Potamilus alatus & 2 & 1.2 & 9 & 5.6 & 9 & 1.4 & 28 & 3.9 \\
\hline 14. Potamilus ohiensis & 2 & 1.2 & 7 & 4.3 & 0 & 0.0 & 2 & 0.3 \\
\hline 15. Truncilla donaciformis & 15 & 8.6 & 27 & 16.8 & 157 & 24.8 & 233 & 32.1 \\
\hline 16. Truncilla truncata & 8 & 4.6 & 15 & 9.3 & 43 & 6.8 & 16 & 2.2 \\
\hline 17. Obliquaria reflexa & 6 & 3.5 & 24 & 14.9 & 2 & 0.3 & 8 & 1.1 \\
\hline 18. Toxolasma parvum & 0 & 0.0 & 0 & 0.0 & 1 & 0.2 & 0 & 0.0 \\
\hline 19. Ligumia recta & 3 & 1.7 & 0 & 0.0 & 1 & 0.2 & 1 & 0.1 \\
\hline 20. Lampsilis r. luteola & 2 & 1.2 & 0 & 0.0 & 0 & 0.0 & 1 & 0.1 \\
\hline 21. Lampsilis cardium & 12 & 6.9 & 1 & 0.6 & 1 & 0.2 & 3 & 0.4 \\
\hline 22. Lampsilis fasciola & 2 & 1.2 & 0 & 0.0 & 0 & 0.0 & 0 & 0.0 \\
\hline Total & 174 & & 161 & & 634 & & 727 & \\
\hline
\end{tabular}

$1=$ Scioto River at US Route 22, Pickaway County, 15 miles downstream of the mouth of Big Walnut Creek (2004); 2 = Scioto River at County Route 4, Pickaway County, 13 miles downstream of the mouth of Big Walnut Creek (2009); 3 = Interstate Route 270, Franklin County, seven miles upstream of the mouth of Big Walnut Creek (2008); 4 = Scioto River at the mouth of Big Walnut Creek (2009) 
(black sandshell) has historically been a member of the mussel fauna of Big Walnut Creek (Watters et al. 2009), it is even more abundant and widely distributed today. It is also one of the mussel species that has experienced significant recovery in the Scioto River (Table 4). In addition, the relatively large number or specimens of $P$. alatus (pink heelsplitter), P. ohiensis (pink papershell), L. fragilis (fragile papershell), and T. truncata (deertoe) suggest a viable connection with the Scioto River, where these species comprise significant components of the mussel fauna of that stream (Table 4).

Other species that have always been common in Big Walnut Creek, such as Tritogonia verrucosa (pistolgrip) and Quadrula quadrula (mapleleaf) also are common today in the Scioto River, which could be a result of exchange from Big Walnut Creek to the Scioto River. It is not too long ago that this portion of the Scioto River was devoid of mussels, but today supports not only mussels, but fish and other invertebrates (OEPA 2012). It is, perhaps, a bit surprising that Truncilla donaciformis (fawnsfoot) has not moved into the lower section of Big Walnut Creek, as this species uses the freshwater drum as host as do many of the other species that have moved into the stream. This species, however, may be a good indicator of improving habitat quality and water quality in Big Walnut Creek as we go forward.

Of special note in the lower section of the creek is the continued presence of $M$. nervosa (washboard) in this reach. One live specimen of this Ohio endangered species was found at Site 16 (off of Lockbourne Road). That species was found alive at this site by Hoggarth (1997) and given that the specimen found during the current survey was 35 years old (annular ring method of determining age), it could easily have been one of the mussels found by Hoggarth more than 16 years ago. This species is on the brink of extirpation from the creek and should be protected from further decline. It has not been found recently in the Scioto River near the mouth of Big Walnut Creek (Table 4) and it is only rarely found in lower Big Darby Creek (Watters et al. 2009). This population, if it is viable, may be the best representation of this species in central Ohio, and could produce specimens that ultimately could populate the Scioto River and Big Darby Creek. Its potential to affect the diversity of mussels is Ohio is quite large.

\section{ACKNOWLEDGMENTS}

We would like to thank the Friends of Big Walnut Creek for funding the study and Otterbein University, Office of Sponsored Programs, for managing the project. Their support of this project made this study possible. This paper was improved by the review process of the Ohio Journal of Science and we thank both the reviewers and the editors for their insightful comments and edits.

\section{LITERATURE CITED}

Hoggarth MA. 1990. A study of the Unionidae of the Olentangy River. Columbus, OH: Ohio Department of Natural Resources, Division of Natural Areas and Preserves.

Hoggarth MA. 1997. Letter to Ohio EPA concerning a permit to discharge water in Big Walnut Creek by S\&S Aggregate, 24 August 1997.

Ohio EPA. 2003. Biological and water quality study of the Big Walnut Creek Basin 2000. Columbus, OH: Ohio EPA. Technical Report DSW/EAS 2003-11-10. [accessed 2016 August 4]. http://www.epa.ohio.gov/portals/35/documents/BigWalnutCreekTSD.pdf

Ohio EPA. 2012. Biological and water quality study of the Middle Scioto River and select tributaries, 2010: Delaware, Franklin, Pickaway, and Union Counties. Columbus, OH: Ohio EPA. Technical Report DSW/EAS 2012-12-12. [accessed 2016 August 4]. http://www.epa.ohio.gov/Portals/35/documents/MiddleSciotoTSD2010.pdf

Ohio EPA. 2015. Biological and water quality study of the Big Darby Creek Watershed. Columbus, OH: Ohio EPA. [accessed 2016 August 4]. http://www.epa.ohio.gov/Portals/35/rules/Big\%20Darby\%20Creek\%20Support $\% 20$ Document.pdf

Watters G T. 1996. Small dams as barriers to freshwater mussels (Bivalvia, Unionoida) and their hosts. Biol. Conserv. 75:79-85. http://doi.org/10.1016/0006-3207(95)00034-8

Watters G T. 1998. Freshwater mussel surveys of the Big Darby Creek System in Central Ohio. Ohio Biological Survey Notes 1: 19-24.

Watters G T, Hoggarth MA, and Stansbery, DH. 2009. The freshwater mussels of Ohio. Columbus, $\mathrm{OH}$ : The Ohio State University Press. 